\title{
MELHORAMENTO DO TRIGO: XIV. CORRELAÇŌES ENTRE A TOLERÂNCIA À TOXICIDADE A DOIS NIVEIS DE ALUMINIO E ALTURA DAS PLANTAS COM OUTROS CARACTERES AGRONÔMICOS EM TRIGO (1)
}

\author{
CARLOS EDUARDO DE OLIVEIRA CAMARGO $(2,3)$
}

\begin{abstract}
RESUMO
Visando estimar as correlaçōes entre a altura das plantas com sete caracteres agronômicos e aquelas entre a tolerância a 1 e $3 \mathrm{mg} /$ litro de $\mathrm{A}^{3+}$ em solução nutritiva com produção de grãos, altura das plantas e número de grãos por espigueta, foram efetuados, no Centro Experimental de Campinas, em 1983, cruzamentos entre o cultivar de trigo $\mathrm{BH}-1146$, com Siete Cerros e Tobari-66. Plântulas representando os pais e as geraçōes F1 e F2 foram testadas para a reação a 1 e $3 \mathrm{mg} / \mathrm{litro}$ de $A \mathrm{P}^{3+}$ em solução nutritiva no laboratório. As plântulas, devidamente identificadas, foram transplantadas em número de quatro por vaso, empregando-se no total 164 vasos dispostos em quatro blocos ao acaso. Os dados referentes à produção de grāos e a outros caracteres agronômicos foram obtidos de plantas individuais em 1984. Os valores da herdabilidade no sentido restrito para comprimento da espiga, número de grãos por espiga, número de grãos por espigueta e número de espigas por planta foram de 0,$79 ; 0,75 ; 0,73$ e 0,68
\end{abstract}

(1) Com recursos complementares do Acordo do Trigo entre as Cooperativas de Produtores Rurais do Vale do Paranapanema e a Secretaria de Agricultura e Abastecimento, por meio do Instituto Agronômico. Trabalho apresentado na XIV Reunião Nacional de Pesquisa de Trigo, Londrina (PR), julho de 1986. Recebido para publicaçăo em 22 de agosto de 1986.

(2) Seção de Arroz e Cereais de Inverno, Instituto Agronómico (IAC), Caixa Postal 28, 13001 Campinas (SP).

(3) Com bolsa de suplementação do CNPq. 
respectivamente, e de 0,$58 ; 0,53$ e 0,50 para número de espiguetas por espiga, altura das plantas e peso de cem grãos respectivamente. Para produção de grãos, o valor estimado foi de 0,38 . Nas populações estudadas, a altura das plantas foi correlacionada com todos os caracteres agronômicos estudados; com exceção de número de grãos por espigueta e peso de cem grãos na populaçāo $\mathrm{BH}-1146 \times$ Tobari-66. A tolerância ao alumínio não foi associada com altura das plantas, número de grãos por espigueta e produção de grāos (com exceção da populaçāo BH-1146 x Tobari-66, quando se utilizou a concentração de $3 \mathrm{mg} /$ litro de $\mathrm{Al}^{3+}$ ), sugerindo ser possivel selecionar plantas que combinam a tolerância ao $\mathrm{Al}^{3+}$, porte semi-anão $\mathrm{e}$ alto potencial produtivo para serem cultivadas nos solos ácidos. Entretanto, grandes populações $\mathrm{F} 2$ seriam necessárias para assegurar a freqüência dos recombinantes desejáveis.

Termos de indexação: trigo, herdabilidade, altura das plantas, produção de grãos, toxicidade de aluminio, toleråncia.

\section{INTRODUÇÃO}

A cultura de trigo é plantada no Estado de São Paulo, em sequeiro, no Vale do Paranapanema e na região Sul. Nessas condições de plantio, para desenvolver todo o potencial de exploração de água e nutrientes, suas plantas precisam de condições de solo favoráveis ao desenvolvimento radicular, especialmente em relação à acidez do solo, por se tratar de uma espécie muito sensivel à toxicidade de aluminio, embora existam diferenças marcantes entre cultivares (CAMARGO \& OLIVEIRA, 1981; CAMARGO et al., 1981; CAMARGO, 1983; KERRIDGE et al., 1971 e LAFEVER et al., 1977).

O aluminio nas camadas superficiais dos solos ácidos pode ser precipitado pela calagem, porém, no subsolo, pode permanecer solúvel e tóxico às plantas, mesmo depois da calagem, que geralmente é feita na camada de solo que atinge no máximo $0,30 \mathrm{~m}$ de profundidade. Nos solos corrigidos por essa prática, o excesso de alumínio trocável ou solúvel no subsolo pode restringir o crescimento das raizes dos cultivares de trigo sensiveis ao alumínio somente para as camadas superficiais que receberam calagem, deixando as plantas mais sensíveis à seca pelo seu impedimento em obter água nas camadas mais profundas (FOY et al., 1965).

Com a introdução da triticultura no cerrado e com a irrigação por aspersão, além da tolerância ao alumínio, os cultivares de trigo necessitam apresentar porte semi-anão, pois, nessas condiçōes, a adubação nitrogenada é utilizada visando ao aumento da produção de grãos, e os cultivares de porte alto tornam-se passiveis de acamamento (CAMARGO et $\mathrm{al}_{\text {, 1985). }}$ 
Trabalhos desenvolvidos por CAMARGO et al. (1980) mostraram que seria possivel selecionar plantas de trigo que combinassem tolerância ao alumínio e porte semi-anão, necessitando, entretanto, grandes populações híbridas em geração F2.

A estimativa da herdabilidade é um instrumento valioso na previsão do progresso genético que segue um programa de seleção para determinado caráter (KETATA et al., 1976).

O estudo das correlações entre caracteres agronômicos de uma população híbrida permite saber se tais caracteres são dependentes ou independentes, isto é, se tendem ou não em permanecer associados nas progênies durante os sucessivos ciclos de seleção (JOHNSON et al., 1966).

O presente trabalho tem por objetivo estudar a herdabilidade em sentido restrito para oito caracteres agronômicos, e as associações entre a tolerância a 1 e $3 \mathrm{mg} /$ /itro de $\mathrm{Al}^{3+}$ em solução nutritiva e a altura das plantas com produção de grãos e outros caracteres agronômicos, a partir de populaçōes híbridas de trigo originárias de cruzamentos entre um cultivar de porte alto e tolerante ao alumínio e dois cultivares de porte baixo e sensiveis ao alumínio.

\section{MATERIAL E MÉTODOS}

Foram estudados os seguintes cultivares: $\mathrm{BH}-1146$ (P1), Tobari-66 (P2) e Siete Cerros (P3). O ' $\mathrm{BH}-1146$ ', de porte alto, é tolerante à toxicidade de aluminio, e 'Tobari-66' e 'Siete Cerros' são de porte semi-anão e respectivamente moderadamente sensivel e sensivel à toxicidade de aluminio (CAMARGO \& OLIVEIRA, 1981).

Foram obtidas as sementes $\mathrm{F} 1$ e $\mathrm{F} 2$ dos cruzamentos ' $\mathrm{BH}-1146^{\prime} \mathrm{x}$ 'Tobari-66' (P1 x P2) e 'BH-1146' x 'Siete Cerros' (P1 x P3). Os pais, F1 s e F2s, foram testados para a tolerância a 1 e $3 \mathrm{mg} / \mathrm{litro}$ de aluminio em solução nutritiva no laboratório, conforme método já publicado (CAMARGO, 1984). As concentrações de $\mathrm{Al}^{3+}$ foram escolhidas baseadas em estudos anteriores, que mostraram ser esses niveis eficientes para a separação de plantas tolerantes e sensiveis ao $\mathrm{Al}^{2+}$ (CAMARGO \& OLIVEIRA, 1981).

Foram utilizadas duas repetiçōes por concentração de $\mathrm{Al}^{3+}$ nas soluções. Em cada repetição, foram escolhidas vinte sementes uniformes de cada cultivar utilizado como genitor, doze sementes de cada cruzamento em geração $\mathrm{F} 1 \mathrm{e}$ quarenta em geraçäo F2.

As plântulas, após cultivadas em soluções de tratamento contendo $1 \mathrm{e}$ $3 \mathrm{mg} / \mathrm{litro}$ por 48 horas, foram removidas para soluções nutritivas completas, onde cresceram por 72 horas. Avaliou-se a tolerância à toxicidade de $\mathrm{Al}^{3+}$ pelo cresci- 
mento da raiz $(\mathrm{mm})$, que foi determinado medindo-se o comprimento da raiz primária central de cada plântula no final das 72 horas na solução nutritiva completa e subtraindo de seu comprimento no final de crescimento na solução de tratamento contendo $\mathrm{Al}^{3+}$.

Após a medição das raizes, as plântulas foram transferidas para vasos cheios de solo adubado sem alumínio trocável, localizados no telado contra o ataque de pássaros no Centro Experimental de Campinas. As plântulas, devidamente identificadas quanto à tolerância a 1 e $3 \mathrm{mg} /$ litro de $\mathrm{Al}^{3+}$ em solução nutritiva, foram plantadas em número de quatro por vaso, equidistantes uma da outra.

O delineamento estatístico empregado foi o de blocos ao acaso com sete tratamentos, os quais incluem os três pais, os dois $F 1 s$ e os dois $F 2 s$, com quatro repetições. As duas primeiras repetições foram constituidas das plantas testadas em soluções de tratamento contendo $1 \mathrm{mg} /$ litro de $\mathrm{Al}^{3+}$, e as duas repetiçōes restantes, das plantas testadas em soluçōes contendo $3 \mathrm{mg} / \mathrm{litro} \mathrm{de} \mathrm{Al}^{3+}$. Cada repetição foi formada por cinco vasos de cada genitor, três vasos de cada híbrido em geração $F 1$, e dez vasos de cada híbrido em geração $F 2$. O conjunto das quatro repetições foi constituído de 164 vasos de plástico preto, de aproximadamente $25 \mathrm{~cm}$ de altura e $20 \mathrm{~cm}$ de diâmetro. Os vasos foram distribuidos distantes um do outro na linha de $10 \mathrm{~cm}$ e entre linhas de $40 \mathrm{~cm}$. Plantou-se uma linha adicional de vasos contornando o experimento, visando minimizar os efeitos de bordadura.

Os dados coletados na base de plantas individuais, no laboratório e em condições de telado, foram os seguintes:

Tolerância ao alumínio - Considerada como o comprimento, em milfmetro, da raiz primária central em 72 horas na solução nutritiva completa, após um tratamento de 48 horas em solução nutritiva contendo 1 e $3 \mathrm{mg} /$ litro de $\mathrm{Al}^{3+}$.

Altura da planta - Medida, em centímetro, do nivel do solo ao ápice das espigas, excluindo as aristas.

Espigas por planta - Considerando apenas o número de colmos com espigas férteis. cada planta.

Produção de grãos - Peso, em gramas, da produção total de grãos de

Comprimento da espiga - Medida, em centímetro, da espiga do colmo principal, excluindo as aristas.

Espiguetas - Computado o número de espiguetas do colmo principal.

Grãos por espiga - Número total de grãos da espiga do colmo princi-

pal.

Grãos por espigueta - Número resultante da divisão do total de grãos da espiga principal pelo total de espiguetas da mesma espiga. 
Peso de cem grãos - Peso, em gramas, de cem grãos coletados ao acaso na produção total da planta.

A média de cada genótipo, em cada repetição, foi usada na análise de variância, cujos efeitos de geração foram divididos em componentes para detectar diferenças dentro e entre gerações. A estimativa da herdabilidade em sentido restrito foi calculada pela regressão da média dos F2 $\mathrm{s}$ em cada repetição sobre a média dos respectivos F1s, na mesma repetição, segundo FALCONER (1960). Foi calculado o coeficiente de determinação pela correlação entre a média dos F2 s e F1s correspondentes (FALCONER, 1960).

As correlaçōes fenotípicas, genotípicas e ambientais foram usadas para estimar o grau de associação entre a altura das plantas e sete outros caracteres agronômicos para cada uma das duas populaçōes (P1 x P2 e P1 x P3). Foram também calculadas as correlações fenotípicas e ambientes entre tolerância a $1 \mathrm{e}$ $3 \mathrm{mg} /$ litro de aluminio e produção de grăos, altura das plantas e número de grãos por espigueta. As correlações usando dados de F1 foram consideradas ambientes e aquelas com dados de F2, fenotípicas, sendo as correlações genéticas, calculadas pela seguinte fórmula:

onde:

$$
r_{F}=\sqrt{H_{x}} \sqrt{H_{Y}} r_{G}+\sqrt{E_{x}} \sqrt{E_{Y}} r_{A}
$$

$r_{F}$ : correlação fenotipica entre os caracteres $x$ e $y$;

$r_{G}$ : correlação genotípica entre $x$ e $y$;

$r_{A}$ : correlação ambiente entre $x$ e $y$;

$\mathrm{H}$ : herdabilidade em sentido restrito com índice $\mathrm{x}$ e y de acordo com $\mathrm{o}$ caráter, e

$\mathrm{E}: 1-\mathrm{H}$, também com índices de acordo com o caráter (FALCONER, 1960).

\section{RESULTADOS E DISCUSSÃO}

Os quadrados médios das análises de variância para os comprimentos nédios das raizes dos sete genótipos de trigo, medidos após 72 horas de crescinento em soluçőes nutritivas completas, seguidos de um pré-crescimento de 48 horas em soluçōes nutritivas de tratamento contendo 1 e $3 \mathrm{mg} /$ litro de $\mathrm{Al}^{3+}$, encontram-se no quadro 1 . Os quadrados médios das análises de variância para zomprimento da espiga, número de espiguetas e de grãos por espiga, peso de zem grãos, número de grãos por espigueta, altura das plantas, número de espigas zor planta e produção de grãos, encontram-se no quadro $2 \mathrm{e}$, as médias de cada jenótipo, para cada um dos caracteres estudados, no quadro 3. 
QUADRO 1. Quadrados médios do comprimento médio das ralzes de diferentes genótipos de trigo medidos após 72 horas de crescimento em soluçōes nutritivas completas que se seguiram a um crescimento de 48 horas em soluçōes nutritivas de tratamento contendo 1 e $3 \mathrm{mg} /$ litro de $\mathrm{Al}^{3+}$

Causas de variação

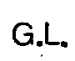

Comprimento da raiz

\begin{tabular}{lccc}
\hline Repetições & 1 & 51,68 & 0,04 \\
Genótipos & 6 & $3215,06^{\star \star}$ & $503,57^{\star \star}$ \\
Entre geraçōes & 2 & $1723,96^{\star}$ & 71,22 \\
Dentro de geraçōes & 4 & $3960,61^{\star \star}$ & $719,75^{\star \star}$ \\
Pais & 2 & $7872,78^{\star \star}$ & $1405,85^{\star \star}$ \\
F1s & 1 & 19,36 & 34,22 \\
F2s & 1 & 77,44 & 33,06 \\
Pais x rep. & 2 & 0,99 & 3,02 \\
F1s x rep. & 1 & 125,44 & 10,56 \\
F2 s x rep. & 1 & 86,49 & 3,06 \\
Entre ger. x rep. & 2 & 45,65 & 15,15 \\
Dentro de ger. x rep. & 4 & 53,46 & 4,92 \\
Genotipos x rep. & 6 & 50,86 & 8,33 \\
Total & 13 & & \\
\hline
\end{tabular}

"Significativo ao nfvel de $5 \%$ pelo teste $F$. ${ }^{* \star}$ Significativo ao nivel de $1 \%$ pelo teste $F$.

QUADRO 2. Quadrados médios da produção média de grăos e sete caracteres agronómicos de diferentes genótipos de trigo plantados em condiçăo de vasos no telado contra pássaros, localizado no Centro Experimental de Campinas

\begin{tabular}{|c|c|c|c|c|c|c|c|c|c|}
\hline $\begin{array}{l}\text { Causas de } \\
\text { variação }\end{array}$ & G.L. & $\begin{array}{l}\text { Compr. } \\
\text { espiga }\end{array}$ & $\begin{array}{c}\text { Espiguetas/ } \\
\text { /espiga }\end{array}$ & $\begin{array}{l}\text { Grảos/ } \\
\text { lespiga }\end{array}$ & $\begin{array}{c}\text { Peso de } \\
\text { cem gräos }\end{array}$ & $\begin{array}{c}\text { Grāos/ } \\
\text { lespigueta }\end{array}$ & $\begin{array}{l}\text { Altura } \\
\text { planta }\end{array}$ & $\begin{array}{l}\text { Espigas/ } \\
\text { /planta }\end{array}$ & $\begin{array}{c}\text { Produçăc } \\
\text { grāos }\end{array}$ \\
\hline & & $\mathrm{cm}$ & $n^{2}$ & $n^{0}$ & 9 & $n^{\circ}$ & $\mathrm{cm}$ & $n^{\circ}$ & $\mathrm{g}$ \\
\hline Repetiçס̄es & 3 & 0,190 & 0,100 & 18,00 & 0,133 & 0,044 & $126,93^{*}$ & $1,168^{*}$ & $7,30^{*}$ \\
\hline Genótipos & 6 & $0,337^{\circ}$ & $3,856^{*}$ & $203,33^{* *}$ & $1,132^{\cdots}$ & $0,708^{*}$ & $503,73^{* *}$ & $0,818^{* *}$ & 2,77 \\
\hline Entre geraçóes & 2 & 0,205 & $6,044^{* *}$ & 18,22 & $1,547^{* *}$ & $0,282^{*}$ & $763,25^{* *}$ & $1,425^{*}$ & 2,44 \\
\hline Dentro de geraçסes & 4 & $0,403^{*}$ & $2,763^{* *}$ & $295,89^{* *}$ & $0,924^{* *}$ & $0,922 *$ & $373,97^{* *}$ & 0,515 & 2,94 \\
\hline Pais & 2 & 0,700 & $4,938^{\star}$ & $391,15^{* *}$ & $1,821^{* \star}$ & $1,489^{* *}$ & $682,41^{* *}$ & 0,660 & 4,12 \\
\hline F1s & 1 & 0,020 & 0,125 & $134,48^{*}$ & 0,038 & $\theta, 312^{*}$ & 124,03 & 0,280 & 0,84 \\
\hline F2s & 1 & $0,180^{* *}$ & 1,051 & $266,81^{* *}$ & 0,015 & $0,396^{*}$ & $7,03^{* *}$ & 0,450 & 2,67 \\
\hline Pais $\times$ rep. & 6 & 0,152 & 0,688 & 5,81 & 0,063 & 0,021 & 8,61 & 0,165 & 2,36 \\
\hline F1 s x rep. & 3 & 0,093 & 0,168 & 7,75 & 0,028 & 0,014 & 18,57 & 0,497 & 2,46 \\
\hline F2s $x$ rep. & 3 & 0,003 & $0,51.1$ & 5,48 & 0,005 & 0,014 & 0,12 & 0,100 & 0,17 \\
\hline Entre ger. $x$ rep. & 6 & 0,175 & 0,380 & 23,59 & 0,088 & 0,038 & 10,72 & 0,103 & 2,37 \\
\hline Dentro de ger. $x$ rep. & 12 & 0,099 & 0,514 & 6,21 & 0,040 & 0,017 & 8,98 & 0,232 & 1,83 \\
\hline Genótipos x rep. & 18 & 0,124 & 0,469 & 12,00 & 0,056 & 0,024 & 9,56 & 0,189 & 2,01 \\
\hline Total & 27 & & & & & & & & \\
\hline
\end{tabular}

- Significativo a $5 \%$ pelo teste $F$. "- Significativo a $1 \%$ pelo teste $F$. 
QUADRO 3. Médias e diferenças mínimas significativas para o comprimento médio das ralzes após 72 horas de crescimento em soluçס̌es nutritivas completas que se seguiu a um crescimento de 48 horas em soluçoes nutritivas de tratamento contendo 1 e 3 mg/latro de A3+. para produçáo media de grăos $\theta$ para sete caracteres agronómicos estudados no ensalo plantado em condiçăo de vașo no telado contra pássaros tocalizado no Centro Experimental de Campinas

\begin{tabular}{|c|c|c|c|c|c|c|c|c|c|c|}
\hline \multirow{2}{*}{ Genólipos } & \multicolumn{2}{|c|}{ Comprimento da raiz } & \multirow{2}{*}{$\begin{array}{l}\text { Compr. } \\
\text { espiga }\end{array}$} & \multirow{2}{*}{$\begin{array}{c}\text { Espiguetas/ } \\
\text { /espiga }\end{array}$} & \multirow{2}{*}{$\begin{array}{l}\text { Grăos/ } \\
\text { /espiga }\end{array}$} & \multirow{2}{*}{$\begin{array}{l}\text { Peso de } \\
\text { cern grăos }\end{array}$} & \multirow{2}{*}{$\begin{array}{l}\text { Grăos/ } \\
\text { /espigueta }\end{array}$} & \multirow{2}{*}{$\begin{array}{l}\text { Altura } \\
\text { planta }\end{array}$} & \multirow{2}{*}{$\begin{array}{r}\text { Espigas/ } \\
\text { /planta }\end{array}$} & \multirow{2}{*}{$\begin{array}{c}\text { Produçãa } \\
\text { grăos }\end{array}$} \\
\hline & $1 \mathrm{mg} /$ itro de $\mathrm{AP}+$ & $+3 \mathrm{mg} /$ litro de $\mathrm{AB}+$ & & & & & & & & \\
\hline & $\mathrm{mm}$ & $\mathrm{mm}$ & $\mathrm{cm}$ & $n^{2}$ & $n^{9}$ & g & $n^{2}$ & $\mathrm{~cm}$ & $n^{0}$ & 9 \\
\hline $\mathrm{BH}-1146$ (P1) & 124,0 & 52,3 & 9,7 & 20,3 & 44,2 & 4,71 & 2,16 & 101,8 & 6,5 & 10,40 \\
\hline Tobari-66 (P2) & 78,9 & 18,3 & 9,0 & 18,1 & 47,8 & 3,77 & 2,65 & 81,1 & 6,3 & 8,37 \\
\hline Siete Cerros $(P 3)$ & 0,0 & 0,0 & 9,8 & 18,6 & 62,8 & 3,40 & 3,38 & 77,6 & 5,7 & 9,50 \\
\hline d.m.s. (5\%) & 5,8 & 10,2 & 0,9 & 1,8 & 5,2 & 0,55 & 0,31 & 6,4 & 0,9 & 3,33 \\
\hline$P 1 \times P 2(F 1)$ & 96,8 & 17,4 & 9,2 & 19.9 & 44,9 & 4,80 & 2,25 & 98,9 & 5.6 & 9,96 \\
\hline $\mathrm{P} 1 \times \mathrm{P} 3(\mathrm{~F} 1)$ & 101,2 & 23,2 & 9,3 & 20,1 & 53,1 & 4,67 & 2,64 & 106,8 & $5.2^{\circ}$ & 10,61 \\
\hline d.m.s. (5\%) & 142,0 & 41,4 & 0.7 & 0,9 & 6,3 & 0,36 & 0,26 & 9,7 & 1,6 & 3,53 \\
\hline$P_{1} \times P_{2}\left(F_{2}\right)$ & 104,1 & 31,5 & 9,4 & 20,2 & 44,1 & 4,50 & 2,22 & 99,5 & 5,1 & 8,71 \\
\hline$P 1 \times P 3(F 2)$ & 95,3 & 25,8 & 9,7 & 20,9 & 55,6 & 4,41 & 2,67 & 101,3 & 5,6 & 9,86 \\
\hline d.m.s. $(5 \%)$ & 118,0 & 27,6 & 0,1 & 1,6 & 5,3 & 0,15 & 0,27 & 0,8 & 0,7 & 0,93 \\
\hline
\end{tabular}

Aplicando-se o teste de Tukey a 5\% para a comparação entre o comprimento da raiz, após um período de 72 horas em solução nutritiva completa, que se seguiu a um crescimento de 48 horas em soluçöes contendo 1 e $3 \mathrm{mg} / \mathrm{litro}$ de $\mathrm{Al}^{3+}$, verificou-se que o 'Siete Cerros' foi señsivel a essas concentrações de $\mathrm{Al}^{3+}$, diferindo significativamente dos cultivares tolerantes $\mathrm{BH}-1146$ e Tobari-66, que, por sua vez, diferiram entre si, sendo ' $\mathrm{BH}-1146$ ' muito mais tolerante, conforme dados já obtidos por CAMARGO \& OLIVEIRA (1981), o que vem provar a hipótese inicial. Não foram detectadas diferenças significativas entre híbridos em geração $\mathrm{F} 1$ e $\mathrm{F} 2$ em relação à tolerância ao $\mathrm{Al}^{\beta+}$. Esses resultados evidenciam que 0 ' $\mathrm{BH}-1146^{\prime}$ mostrou-se promissor em transmitir, para suas progênies, a característica "maior tolerância à toxicidade de $\mathrm{Al}^{3+\text { " }}$, confirmando resultados anteriores revelando que ' $\mathrm{BH}-1146$ ' possula um par de genes dominantes para a tolerância ao $\mathrm{Al}^{3+}$, que se mostrou eficiente mesmo em concentrações mais elevadas desse elemento, como $10 \mathrm{mg} /$ litro nas soluções nutritivas (CAMARGO, 1981).

Em relação ao comprimento da espiga, nāo se encontraram diferenças significativas entre os pais e os $\mathrm{F} 1 \mathrm{~s}$. O genótipo ' $\mathrm{BH}-1146$ ' x 'Tobari-66' em geração F2 apresentou espigas mais compridas, diferindo significativamente do genótipo 'BH-1146' x 'Siete Cerros', em geração F2. Apesar dessa diferença significativa, verificou-se baixa variabilidade genética para esse caráter entre os pais utilizados, sugerindo reduzida possibilidade em selecionar plantas com espigas mais compridas do que os pais nas populações originárias dos híbridos entre eles.

$\mathrm{O}$ 'BH-1146' apresentou maior número de espiguetas por espiga, diferindo significativamente, porém, somente do 'Tobari-66'. Não houve diferenças significativas entre os $\mathrm{F} 1 \mathrm{~s}$ e os $\mathrm{F} 2 \mathrm{~s}$ em relação ao número de espiguetas por es- 
piga, mostrando que 'BH-1146', em cruzamentos, foi promissor para transmitir a descendentes a característica "maior número de espiguetas por espiga".

Considerando o número de grãos por espiga, 'Siete Cerros' mostrou maior índice, diferindo significativamente dos outros dois. $\mathrm{O}$ híbrido ' $\mathrm{BH}-1146$ ' $\mathrm{x}$ 'Siete Cerros' em geraçōes F1 e F2 diferiu do 'BH-1146' x 'Tobari-66', que apresentou o menor número de grãos por espiga. Como já foi observado em trabalhos anteriores (CAMARGO \& OLIVEIRA, 1983, e CAMARGO, 1984), 'Siete Cerros' mostrou-se promissor para transmitir a descendentes a característica "maior número de grãos por espiga".

$\mathrm{O}$ ' $\mathrm{BH}-1146$ ' foi o que apresentou grãos mais pesados, diferindo do 'Siete Cerros' e 'Tobari-66'. Entre os F1s e os F2s, nāo se observaram diferenças significativas em relação a esse parâmetro. Os resultados indicaram que o ' $\mathrm{BH}-1146$ ' poderia ser utilizado como fonte de grãos mais pesados no programa de melhoramento genético, em virtude de se mostrar eficiente em transmitir essa caracteristica às suas progênies.

Considerando o número de grãos por espigueta, 'Siete Cerros' destacou-se, diferindo significativamente dos outros cultivares. O genótipo ' $\mathrm{BH}-1146$ ' $\times$ 'Siete Cerros', em gerações F1 e F2, apresentou maior número de grãos por espigueta do que o 'BH-1146' × 'Tobari-66', deles diferindo significativamente. 'Siete Cerros' apresentou grande potencial em transferir para suas progênies a caracteristica "maior numero de grãos por espigueta", confirmando resultados obtidos por CAMARGO (1984).

Os cultivares Siete Cerros e Tobari-66 apresentaram-se como os de menor altura, nāo diferindo entre si, porém diferindo significativamente do ' $\mathrm{BH}-1146$ ', que exibiu porte alto. Não foram detectadas diferenças entre os dois híbridos, em geração $\mathrm{F} 1$, em relação a esse parâmetro. O híbrido ' $\mathrm{BH}-1146$ ' x. 'Siete Cerros', em geração F2, teve as plantas mais altas, diferindo significativamente do hibrido $\mathrm{BH}-1146 \times$ Tobari-66, em geração F2. Os dados obtidos sugerem que os genes para porte baixo, encontrados nos cultivares Siete Cerros e Tobari-66, têm um comportamento parcialmente recessivo, ao passo que os genes para porte alto, encontrados em 'BH-1146', apresentaram um comportamento parcialmente dominante. Esses resultados estão de acordo com os obtidos por CAMARGO et al. (1980) e CAMARGO \& OLIVEIRA (1983).

Os três cultivares não diferiram entre si em relação ao número de espigas por planta. Também não foram observadas diferenças significativas entre os F1s e F2s, em relação a esse parâmetro, existindo, portanto, pequena variabilidade genética para esse caráter nas populações estudadas.

Em relação à média de produção de grãos, não se detectaram diferenças significativas entre os cultivares pais, F1s e F2s, apesar de as médias das populaçōes $\mathrm{F} 1$ serem superiores às médias de ambos os pais, evidenciando heterose para esse caráter. Esses resultados também foram obtidos por JOHNSON et al. (1966), CAMARGO \& OLIVEIRA (1983) e CAMARGO (1984), que afirmaram 
haver grande influência do ambiente sobre a produção de grãos de plantas individuais, mesmo dentro de condiçōes de preciso espaçamento das plantas.

As estimativas da herdabilidade em sentido restrito $\left(H_{N S}\right)$, derivadas de dados obtidos pela regressão dos F2s sobre as médias dos respectivos $F 1 s$, bem como os coeficientes de determinação $\left(R^{2}\right)$ originários de dados obtidos pela correlação entre a média dos F2s e F1s correspondentes, para oito caracteres estudados, encontram-se no quadro 4.

Os valores da herdabilidade em sentido restrito, estimados para os caracteres agronômicos estudados, com exceção da produção de grãos, variaram de 0,50 a 0,79 , indicando que grande parte da variabilidade genética total está associada a uma ação aditiva de genes.

O valor significativo do coeficiente de determinação, calculado para número de grãos por espigueta, indicou que alta porcentagem da variabilidade observada para esse caráter nas progênies seria proveniente da variação encontrada nos pais, sugerindo que a seleção para esse caráter seria eficiente nas primeiras gerações segregantes. Para os demais caracteres, que apresentaram coeficientes de determinação baixos e não-significativos, as seleçōes poderiam ser efetuadas nas últimas geraçōes, quando o valor genético da progênie seria mais precisamente determinado.

As correlaçōes ambientes $\left(r_{A}\right)$, fenotipicas $\left(r_{F}\right)$ e genéticas $\left(r_{G}\right)$, entre altura da planta e sete outros caracteres agronómicos, para os cruzamentos entre 'BH-1146', de porte alto, e os dois cultivares mexicanos, de porte semi-anão, encontram-se no quadro 5.

QUADRO 4. Estimativas das herdabilidades em sentido restrito $\left(H_{N S}\right)$ e dos coeficientes de determinação $\left(R^{2}\right)$ para todos os caracteres agronômicos estudados, derivados de dados obtidos nas geraçōes F1s e F2s de cruzamentos envolvendo o ' $\mathrm{BH}-1146$ ', e os cultivares Tobari- 66 e Siete Cerros

Caráter

$H_{\text {NS }}$

$\mathrm{R}^{2}$

Altura das plantas $(\mathrm{cm}) \ldots \ldots \ldots \ldots \ldots \ldots$.

$\begin{array}{ll}0,53 \pm 0,21 & 0,52 \\ 0,38 \pm 0,14 & 0,56 \\ 0,79 \pm 0,24 & 0,65 \\ 0,58 \pm 0,45 & 0,23 \\ 0,75 \pm 0,26 & 0,58 \\ 0,73 \pm 0,21 & 0,67^{\star} \\ 0,50 \pm 0,17 & 0,58 \\ 0,68 \pm 0,22 & 0,62\end{array}$

Produção de grãos $(g) \ldots \ldots \ldots \ldots \ldots \ldots \ldots$

Comprimento da espiga $(\mathrm{cm}) \ldots \ldots \ldots \ldots \ldots$.

Espiguetas/espiga $\left(n^{0}\right) \ldots \ldots \ldots \ldots \ldots \ldots$

Grãos/espiga $\left(n^{0}\right) \ldots \ldots \ldots \ldots \ldots \ldots \ldots \ldots$

Grắos/espigueta $\left(n{ }^{9}\right) \ldots \ldots \ldots \ldots \ldots \ldots \ldots$

Peso de cem grãos $(\mathrm{g}) \ldots \ldots \ldots \ldots \ldots \ldots \ldots$

Espigas/planta ( $\mathrm{n}^{\circ}$ )

$0,68 \pm 0,22$ 0,62

\footnotetext{
- Significativo ao nivel de $5 \%$.
} 
QUADRO 5. Correlaçōes de ambiente $\left(r_{A}\right)$ e fenotipicas $\left(r_{F}\right)$ entre altura das plantas e outros caracteres agronômicos para cruzamentos de trigo envolvendo o ' $\mathrm{BH}-1146$ ' e os cultivares Tobari-66 e Siete Cerros

\begin{tabular}{|c|c|c|c|}
\hline $\begin{array}{l}\text { Caráter correlacionado } \\
\text { com altura da planta }\end{array}$ & & $\begin{array}{c}\text { 'BH-1146' } \\
x \\
\text { 'Tobari-66' }\end{array}$ & $\begin{array}{c}\text { 'BH-1146' } \\
\mathrm{x} \\
\text { 'Siete Cerros' }\end{array}$ \\
\hline \multirow[t]{3}{*}{ Comprimento da espiga } & $r_{A}$ & $0,423^{* *}$ & $0,311^{*}$ \\
\hline & $\mathrm{r}_{\mathrm{F}}$ & $0,292^{\star \star}$ & 0,387 \\
\hline & $r_{G}$ & 0,245 & 0,446 \\
\hline \multirow[t]{3}{*}{ Número de espiguetas/espiga } & $r_{\mathrm{A}}$ & $0,391^{\star \star}$ & 0,257 \\
\hline & $r_{F}$ & $0,404^{\star \star}$ & $0,217^{\star}$ \\
\hline & $r_{G}$ & 0,414 & 0,186 \\
\hline \multirow[t]{3}{*}{ Número de grãos/espiga } & $r_{A}$ & $0,534^{\star \star}$ & 0,260 \\
\hline & $\mathrm{r}_{\mathrm{F}}$ & $0,208^{*}$ & $0,498^{\star *}$ \\
\hline & $r_{G}$ & 0,040 & 0,647 \\
\hline \multirow[t]{3}{*}{ Número de grãos/espigueta } & $\mathrm{r}_{\mathrm{A}}$ & $0,542^{* \star}$ & 0,073 \\
\hline & $r_{F}$ & 0,076 & $0,380^{\star *}$ \\
\hline & $r_{G}$ & $-0,185$ & 0,565 \\
\hline \multirow[t]{3}{*}{ Peso de cem grãos } & $r_{A}$ & $0,874^{\star \star}$ & 0,267 \\
\hline & $r_{F}$ & 0,040 & $0,216^{* \star}$ \\
\hline & $r_{G}$ & $-0,747$ & 0,169 \\
\hline \multirow[t]{3}{*}{ Produção de grãos } & $r_{A}$ & $0,644^{\star \star}$ & $0,443^{\star \star}$ \\
\hline & $r_{F}$ & $0,239^{\star *}$ & $0,501^{\star *}$ \\
\hline & $r_{G}$ & $-0,237$ & 0,582 \\
\hline \multirow[t]{3}{*}{ Número de espigas/planta } & $r_{A}$ & $0,561^{* *}$ & $0,340^{*}$ \\
\hline & $r_{F}$ & 0,109 & $0,332^{* *}$ \\
\hline & $r_{G}$ & $-0,181$ & 0,332 \\
\hline
\end{tabular}

* Significativo ao nivel de $5 \%$. ${ }^{* *}$ Significativo ao nivel de $1 \%$.

Considerando a população $\mathrm{BH}-1146$ × Tobari-66, verifica-se que as correlações fenotípicas entre altura da planta e comprimento da espiga, número de espiguetas por espiga e produção de grãos, foram positivas e altamente significativas ao nivel de $1 \%$. A correlação fenotipica entre a altura da planta e o número de grãos por espiga foi positiva e significativa ao nivel de $5 \%$. Não se detectaram correlaçōes fenotípicas significativas entre a altura da planta e número de grãos por espigueta, peso de cem grãos e número de espigas por planta. 
As correlaçōes fenotípicas entre a altura da planta e os demais caracteres agronômicos foram positivas e altamente significativas, ao nível de $1 \%$, para a população $\mathrm{BH}-1146 \times$ Siete Cerros, exceto entre a altura da planta e o número de espiguetas por espiga, que foi positiva e significativa ao nivel de $5 \%$.

No quadro 6 , encontram-se as correlações ambientes $\left(r_{A}\right)$ e fenotipicas $\left(r_{F}\right)$ entre o comprimento da raiz medida após 72 horas em solução nutritiva completa, seguida de um tratamento de 48 horas em soluçōes nutritivas contendo 1 e $3 \mathrm{mg} /$ litro de $\mathrm{Al}^{3+}$, e produção de grãos, altura das plantas e número de grãos por espigueta (fertilidade da espiga), para os cruzamentos de trigo envolvendo o ' $\mathrm{BH}$ 1146', tolerante à toxicidade de $\mathrm{A}^{3+}$, e os cultivares Tobari-66 e Siete Cerros, moderadamente sensivel e sensivel respectivamente.

QUADRO 6. Correlações de ambiente $\left(r_{A}\right)$ e fenotípicas $\left(r_{F}\right)$ entre os comprimentos das raízes medidas após 72 horas em soluçōes nutritivas completas, seguidas de um tratamento de 48 horas em soluções contendo 1 e $3 \mathrm{mg}$ hitro de $\mathrm{A}^{3+}$ com três outros caracteres agronômicos envolvendo os cruzamentos entre o ' $\mathrm{BH}-1146$ ' e os cultivares Tobari-66 e Siete Cerros

\begin{tabular}{|c|c|c|c|}
\hline $\begin{array}{l}\text { Caráter correlacionado } \\
\text { com comprimento da raiz } \\
\left(1 \mathrm{mg} / \text { litro de } \mathrm{Al}^{3+}\right)\end{array}$ & & $\begin{array}{l}\text { 'BH-1146' } \\
\mathrm{x} \\
\text { 'Tobari-66' }\end{array}$ & $\begin{array}{c}\text { 'BH-1146’ } \\
x \\
\text { 'Siete Cerros' }\end{array}$ \\
\hline \multirow[t]{2}{*}{ Produção de grãos } & $r_{A}$ & $0,629^{* *}$ & $0,639^{* *}$ \\
\hline & $r_{F}$ & 0,003 & 0,177 \\
\hline \multirow[t]{2}{*}{ Altura das plantas } & $r_{A}$ & $0,666^{\star \star}$ & 0,161 \\
\hline & $r_{F}$ & $-0,136$ & 0,009 \\
\hline \multirow[t]{2}{*}{ Número de grãos/espigueta } & $r_{A}$ & 0,378 & $-0,177$ \\
\hline & $r_{F}$ & 0,001 & 0,043 \\
\hline \multirow{2}{*}{\multicolumn{2}{|c|}{$\begin{array}{l}\text { Carăter correlacionado } \\
\text { com comprimento da raiz } \\
\left(3 \mathrm{mg} / \text { litro de } \mathrm{Al}^{3+}\right)\end{array}$}} & 'BH-1146' & 'BH-1146' \\
\hline & & $\begin{array}{c}x \\
\text { 'Tobari-66' }\end{array}$ & $\stackrel{x}{\text { 'Siete Cerros' }}$ \\
\hline \multirow[t]{2}{*}{ Produção de grāos } & $r_{A}$ & $0,461^{* *}$ & 0,114 \\
\hline & $r_{F}$ & $0,272^{\star}$ & 0,178 \\
\hline \multirow[t]{2}{*}{ Altura das plantas } & $r_{A}$ & $0,433^{*}$ & 0,101 \\
\hline & $r_{F}$ & 0,172 & 0,152 \\
\hline \multirow[t]{2}{*}{ Número de grãos/espigueta } & $r_{\mathrm{A}}$ & 0,334 & $-0,305$ \\
\hline & $r_{F}$ & 0,216 & $-0,012$ \\
\hline
\end{tabular}

* Significativo ao nivel de $5 \%$. ** Significativo ao nivel de $1 \%$. 
Nos cruzamentos estudados, a tolerância a 1 e $3 \mathrm{mg} /$ litro de $\mathrm{Al}^{3+}$ não foi associada com produção de grãos (com exceção da correlação fenotípica no cruzamento $\mathrm{BH}-1146 \times$ Tobari-66, usando-se a tolerância a $3 \mathrm{mg} / \mathrm{litro}$ de $\mathrm{Al}^{3+}$ ), altura das plantas e número de grãos por espigueta. Considerando essas correlações e que a altura das plantas foi associada significativamente com produção de grãos para as duas populaçōes e a altura das plantas, associada significativamente com número de grãos por espigueta para a população ' $\mathrm{BH}-1146$ ' $\mathrm{x}$. 'Siete Cerros', verifica-se que haveria necessidade de grandes populações F2 para assegurar maior freqüência dos recombinantes desejáveis, isto é, tolerantes ao alumínio, de porte semi-anão, com maior fertilidade da espiga, com alto potencial produtivo, que seriam adaptados à maioria dos solos ácidos existentes nas regiōes tritícolas paulistas.

\author{
SUMMARY \\ WHEAT BREEDING: \\ XIV. CORRELATIONS OF TOLERANCE TO TWO LEVELS \\ OF ALUMINUM TOXICITY AND PLANT HEIGHT \\ WITH OTHER AGRONOMIC CHARACTERISTICS IN WHEAT
}

The standard height and $\mathrm{Al}$ tolerant cultivar $\mathrm{BH}-1146$ was crossed with semi-dwarf and Al sensitive cultivars Tobari-66 and Siete Cerros, in 1983. Parents, F1's and F2's were tested for their reaction to 1 and $3 \mathrm{mg} / \mathrm{l}$ of $\mathrm{Al}^{3+}$ in nutrient solution, in laboratory condition and evaluated for grain yield, plant height, number of spikes per plant, number of spikelets per spike, number of grains per spike, number of grains per spikelet, 100-grain-weight and spike length at maturity in an experiment using pots, under a screen house at Experimental Center of Campinas, State of São Paulo, Brazil, in 1984. Medium to high narrow sense heritability estimates were obtained for spike length, number of grains per spike, number of grain per spikelet and number of spikes per plant; and medium to low for other agronomic characteristics under study. Plant height was significantly correlated with all the agronomic characteristics under study, except number of grains per spikelet and 100-grain-weight in the ' $\mathrm{BH}-1146^{\prime} \times$ 'Tobari- $66^{\prime}$ ' population. Tolerance to $\mathrm{Al}^{3+}$ toxicity was not associated with grain yield (except for the population from the cross $\mathrm{BH}-1146 \times$ Tobari-66 using $3 \mathrm{mg} / /$ of $\mathrm{Al}^{3+}$ ), plant height and number of grain per spikelet. The results suggested that it is possible to select plant types that combine $A^{3}+$ tolerance, semi-dwart height levels and high yield potential to be cultivated on aluminum acid soils. However, larger F2 populations would be required to ensure the frequency of desired recombinants.

Index terms: wheat, narrow sense heritability, plant height, aluminum toxicity, tolerance, grain yield, number of grain per spikelet. 


\section{REFERÊNCIAS BIBLIOGRÁFICAS}

CAMARGO, C.E.O. Efeito da temperatura da solução nutritiva na tolerância ao alumínio de cultivares de trigo. Bragantia, Campinas, 42:51-63, 1983.

- Melhoramento do trigo. I. Hereditariedade da tolerância à toxicidade do aluminio. Bragantia, Campinas, 40:33-45, 1981.

- Melhoramento do trigo. VIII. Associaçōes entre produção de grãos e outros caracteres agronômicos em populaçōes hibridas envolvendo diferentes fontes de nanismo. Bragantia, Campinas, 43(2):541-552, 1984.

. Melhoramento do trigo. X. Estimativas da herdabilidade e correlaçōes entre tolerância à toxicidade de aluminio e produção de grãos com outros caracteres agronômicos em trigo. Bragantia, Campinas, 43(2):615-628, 1984.

; FELÍCIO, J.C.; FREITAS, J.G.; FERREIRA FILHO, A.W.P.; RAMOS, V.J. \& PETTINELLI JÜNIOR, A. Adubação N, $P$. K e $S$ para a cultura do trigo no Estado de São Paulo. In: REUNIĀO DA COMISSÃO CENTRO-SULBRASILEIRA DE PESQUISA DE TRIGO, 1., Londrina, 1985. 25p. (Mimeo)

; KRONSTAD, W.E. \& METZGER, R.J. Parent-progeny regression estimates and associations of height level with aluminum toxicity and grain yield in wheat. Crop Science, 20:355-358, 1980.

\& OLIVEIRA, O.F. Melhoramento do trigo. V. Estimativas da herdabilidade e correlaçōes entre altura, produção de grãos e outros caracteres agronômicos em trigo. Bragantia, Campinas, 42:131-148, 1983.

_ \& _- Tolerância de cultivares de trigo a diferentes niveis de aluminio em solução nutritiva e no solo. Bragantia, Campinas, 40:21-31, 1981.

\& LAVORENTI, A. Efeito de diferentes concentrações de sais em solução nutritiva na tolerância de cultivares de trigo à toxicidade de aluminio. Bragantia, Campinas, 40:93-101, 1981.

FALCONER, D.S. Introduction to quantitative genetics. New York, Ronaid Press, 1960. $365 p$.

FOY, C.D.; ARMIGER, W.H.; BRIGGLE, L.W. \& REID, D.A. Differential aluminum tolerance to wheat and barley varieties in acid soils. Agronomy Journal, 57:413-417, 1965.

.JOHNSON, V.A.; BIRVER, R.J.; HAUNOLD, A. \& SCHMIDT, J.N. Inheritance of plant height and seed characteristics in a cross of hard red winter wheat (Triticum aestivum L.). Crop Science, 6:336-338, 1966.

KERRIDGE, P.C.; DAWSON, M.D. \& MOORE, D.P. Separation of degrees of aluminum tolerance in wheat. Agronomy Journal, 63:586-591, 1971.

KETATA, H.; EDWARDS, L.W. \& SMITH, E.L. Inheritance of eight agronomic characters in a winter wheat cross. Crop Science, 16:19-22, 1976.

LAFEVER, H.N.; CAMPBELL, L.G. \& FOY, C.D. Differential response of wheat cultivars to Al. Agronomy Journal, 69:563-568, 1977. 